\title{
DECADIMENTO DEL MODULO ELASTICO IN ROCCIA A CONTATTO CON BACINI IDRICI ARTIFICIALI $(*)$
}

\author{
P. Caloi - M. C. Spadea
}

1. - Negli ultimi anni abbiamo avuto occasione di determinare il modulo elastico di diversi sistemi rocciosi con il metodo sismico. $\grave{E}$ ben noto in cosa consista questo metodo; perciò riteniamo superfluo soffermarci a richiamarlo, sia pure sommariamente.

Le registrazioni delle vibrazioni, determinate nella roccia dal brillamento di opportune cariche esplosive, venivano eseguite con l'ausilio di un fotovibrometro "Askania" a tre componenti. Ciò consentiva anche, in molti casi, il rilevamento delle onde trasversali.

Le prove sono state eseguite in alcune località delle Alpi Orientali, dalle Dolomiti della Marmolada alle prealpi Carniche.

In molti casi, scopo di queste prove è stata la determinazione delle caratteristiche elastiche della roccia di certe strette vallive, destinate ad ancorare grandi dighe di sharramento per centrali idroelettriche. La conoscenza del modulo elastico (modulo di Young) medio della roccia ambiente serviva agli ingegneri progettisti per la scelta del calcestruzzo più adatto alla diga progettata.

Fra le diverse determinazioni eseguite, c'è stata quella relativa alla stretta del Piave a Pieve di Cadore, dove è stata costruita una diga di sbarramento (fig. 1). Le prime determinazioni del modulo della occia in questa localita furono fatte nel 1948-49, prima e durante la costruzione della diga stessa.

Per quanto riguarda il complesso roccioso, costituente la spalla destra della diga di Pieve di Cadore (fig. 1-a) le esperienze da noi condotte nell'epoca detta, portarono ad ottenere per il modulo elastico un valore medio di $480.000 \mathrm{~kg} / \mathrm{cm}^{2}$.

Terminate la diga nel 1949, il bacino cosi formato venne riempito, dando origine ad un grande lago artificiale. Nel maggio 1951 il bacino fu completamente svasato; anche negli anni successivi, il li-

(*) Comunicazione presentata alla "Association Internationale de Séismologie et Physique de l'intérieur de la Terre » nella X Assemblea Generale dell' U.G.G.I. Roma 1954. 
vello delle acque subi variazioni più o meno notevoli, senza per altro giungere più allo sruotamento completo.

Nel 1952 ci fu sugrwerito di ripetere le esperienze nella roccia della spalla destra, per una sorta di controllo. Le registrazioni furono rifetute lungo gli stessi prolili, rispettando le condizioni in cui furono eseguite nel 1949.

Con nostra sorpresa, questa volta il modulo elastico della roccia appariva sensibilmente diminuito: il suo valor medio infatti non superava i $350.000 \mathrm{kgr} / \mathrm{cm}^{2}$.

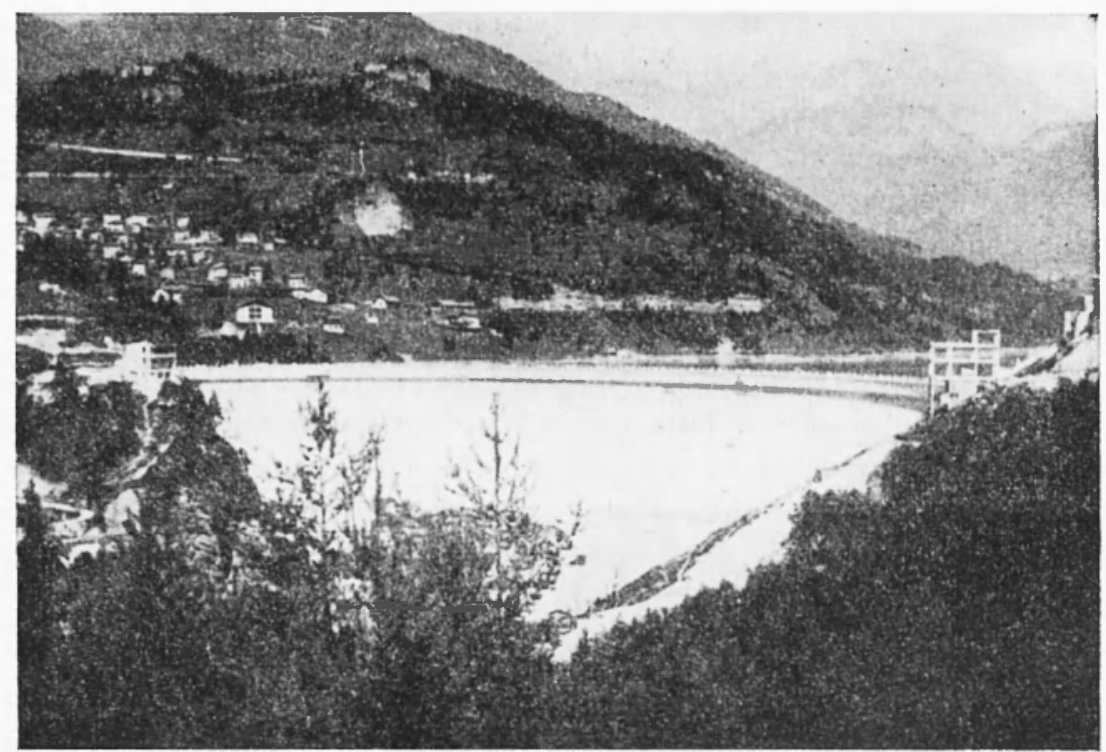

Fiŕ. 1

Nellestate del 1953 le esperienze vennero ripetute, a scopo di verifica: il risultato ottenuto confermò quello del 1952.

Il modulo elastico della roccia in spalla destra della diga di Pieve di Carlore aveva quindi subito dal 1949, cpoca del primo invaso, al 1952 una sensibile diminuzione: $e$ a questa diminuzione che noi asectriamo la qualifica di decadimento.

Abbiamo ritenuto utile controllare questo risultato su altre dighe. A quota di circa $1000 \mathrm{~m}$, a Sauris, nelle Alpi Carniche, esiste una grande diga (dell'altezza di $136 \mathrm{~m}$, costruita nella valle del Lumiei (affluente di sinistra del Tagliamento) nel 1916. Qui le esperienze furono 
condotte a valle e a monte della diga. Il risultato fu una conferma di quello ottenuto a Pieve: mentre a valle della diga il modulo di Young risultó di 1.000 .000 ca. $\mathrm{di} \mathrm{kg} / \mathrm{cm}^{2}$ a monte il suo valore si aggirò sugli $800.000 \mathrm{~kg} / \mathrm{cm}^{2}$. Anche qui vi fu decadimento nella zona

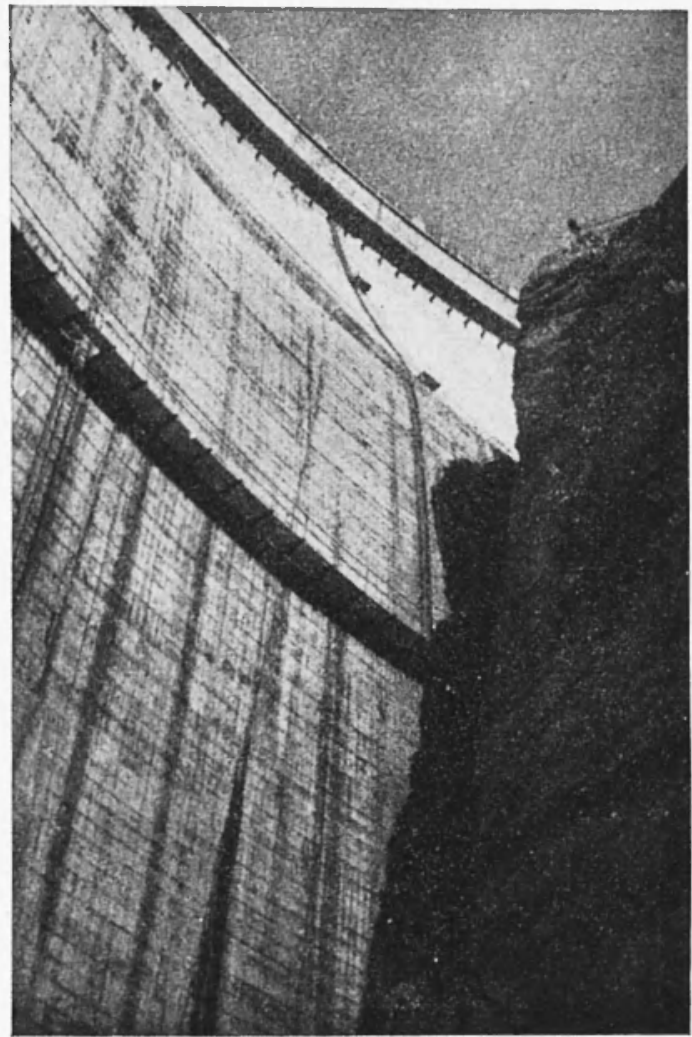

Fig. I $a$

interessata dalle acque, sehhene la sua entitì sia slata alquanto minore di quella osservata a Pieve di Cadore.

A quale causa può essere attriluuito tale decadimento? ì quanto ci siamo proposti di chiarire.

2. - Come i noto, nei corpi naturali l'elasticiti si complica sempre, in minore o magrior misura, con alte proprieta della materia, quali l'attrito interno, la viscosita, la plasticita, ece. Sebhene le ricerche su questo argomento risentano ancora di una certa confusione 
di definizioni ed urtino contro sensibili difficoltà, ogrgi i possibile. poter sceverare - talvolta con suffeiente approssimazione -- le caralteristiche prettamente clastiche di una roceia, da quelle derivanti dall'attrito interno o dalla viscosita.

Dato lo scopo della nostra esposizione, ci limiteremo a ritenere la roceia come perfettamente clastica e le deformazioni, cui viene sottoposta, come verificantisi nell'ambito della legge di Hooke.

Si sa che, commemente, l'elasticita di una roceia viene indirata con i valori che assume il modulo di Youmer inteso come il rapporto

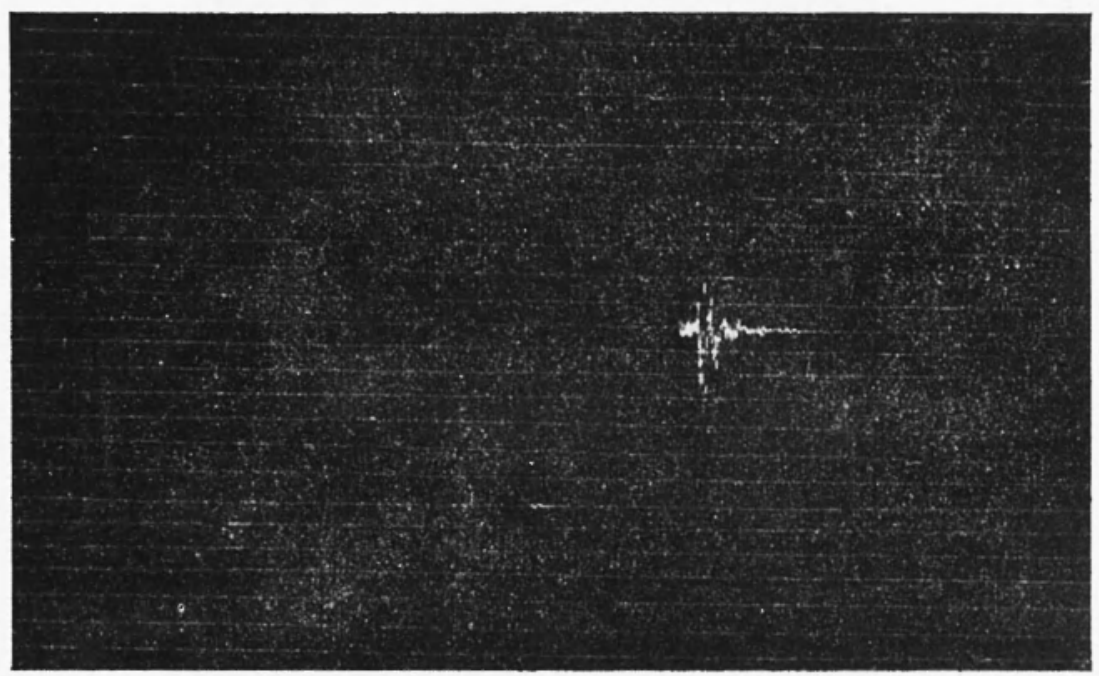

Fir. 2. Piccolo terremolo di energia media dellordine di 2.1011 erk.

fra il carieo e il coefficiente d'allungamento lineare di un elemento del materiale in esame.

Non ei softermeremo sui metodi in uso per la determinazione di questa grandezza. Diremo soltanto che, specie per materiali non compatti, quali greneralmente sono le rocee afforanti, i metodi statici con:ducono a valori di attendibilita limitata, per quel complesso di fenomeni di elasticita susseguente, che si verificano sempre nelle esperienze di più o meno lumga durata. Senza tener conto di tutte le alterazioni - praticamente inevitabili -, consegruenti alla porositi della roccia.

1 metodi dinamici presentano il grande vantagrgio di valersi della registrazione di fenomeni istantanei, fuali la propagazione di onde sismiche, comunque destate nella roccia. 


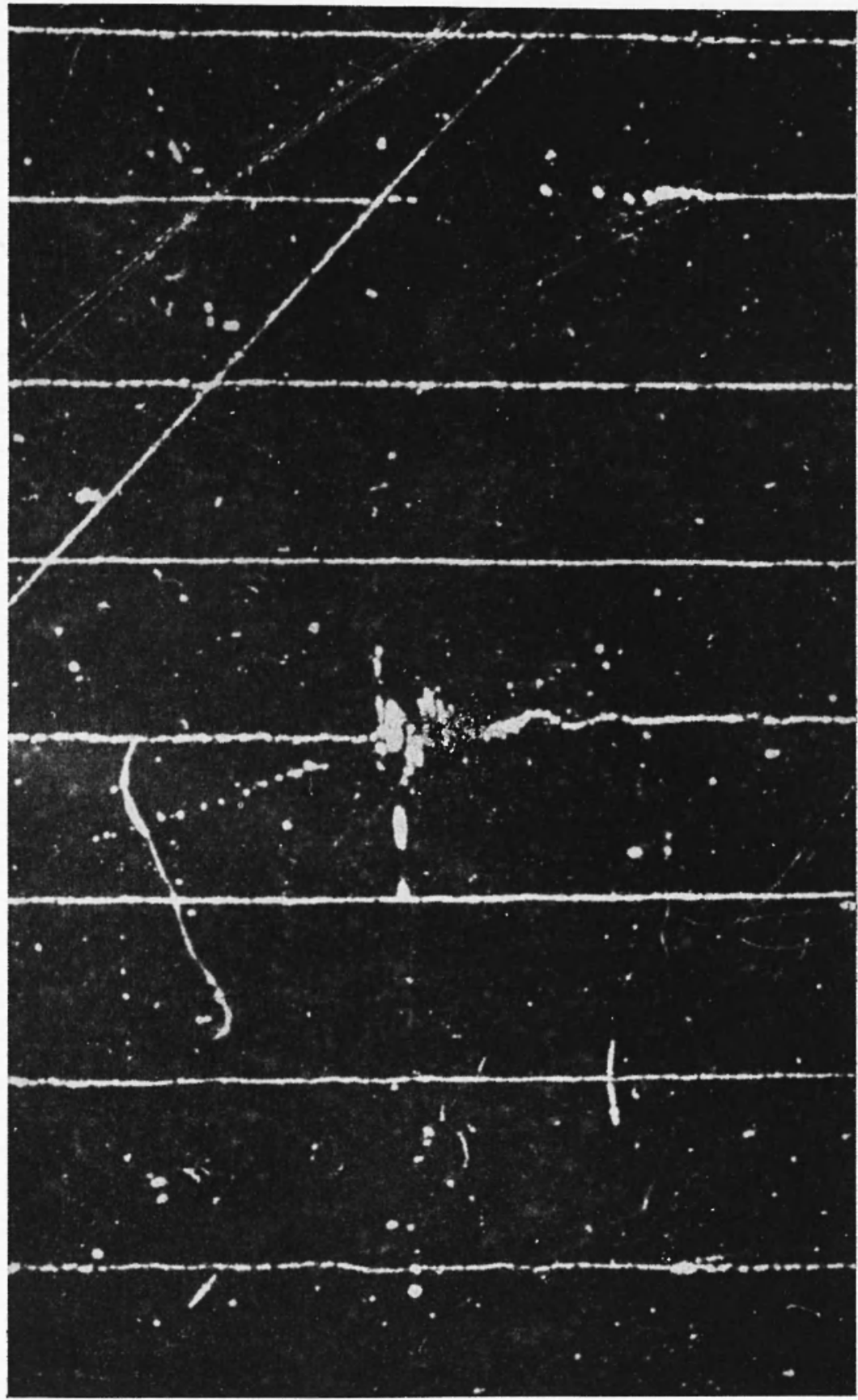

Fig. 3 - Scossetta di energia media di $2.10^{12}$ erg. 


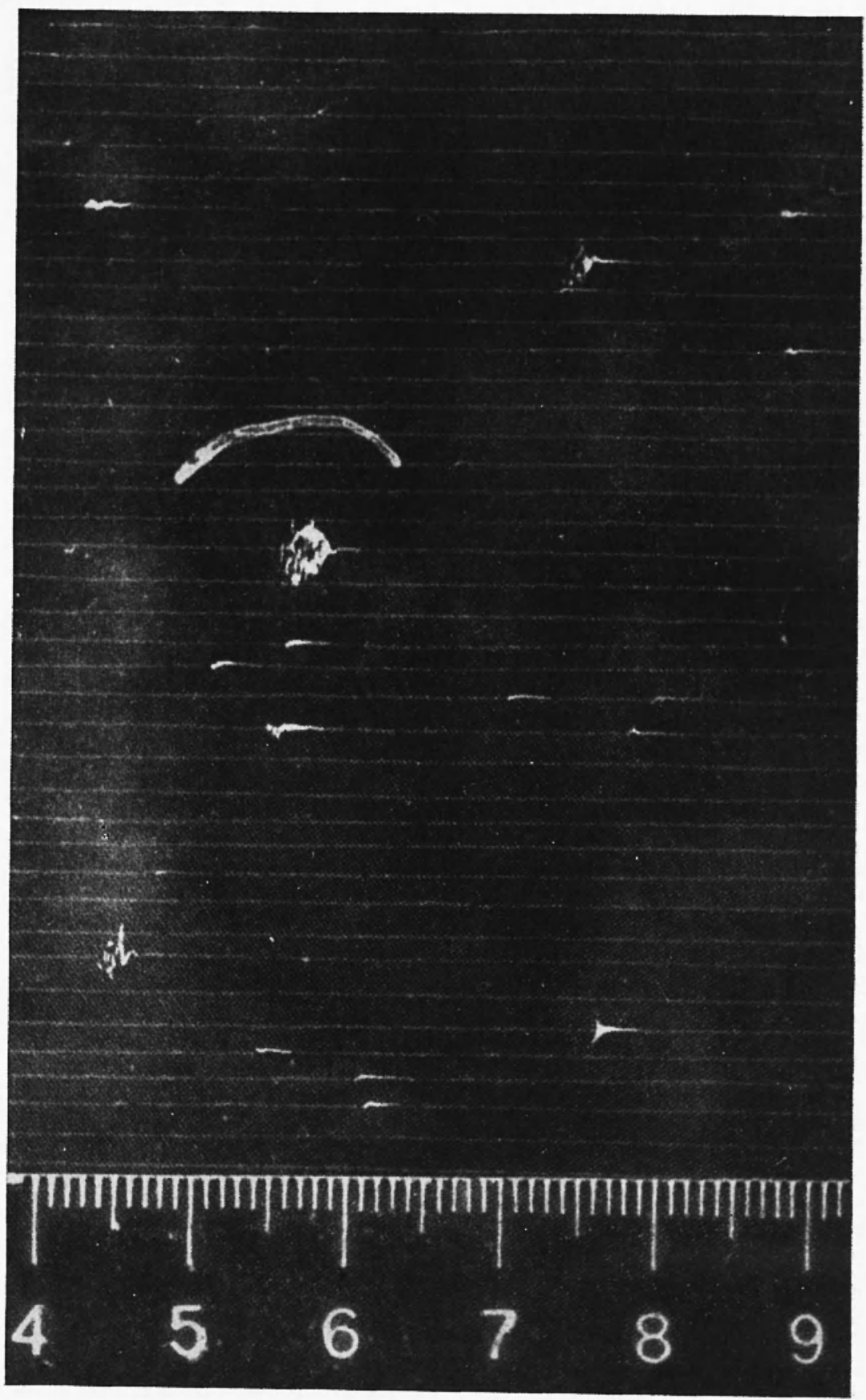

Fig. 4. 
Ecco perché noi abljiamo preferito ricorrere al metodo sismico, il quale consente altresi la ripetizione delle esperienze in loco, nelle stesse condizioni iniziali.

A cosa attribuire il constatato decadimento del modulo elastico della roccia presso la diga di Pieve di Cadore? Tale decadimento, evidentemente, si traduce in pratica in una diminuzione della velocità di propagazione delle onde elastiche: ed è appunto questo che noi abljiamo appurato. La velocità delle onde longitudinali, per es., nella roccia in qustione, da un valore di $4,5 \mathrm{~km} / \mathrm{sec}$. quale aveva nel 1949, è scesa nel 1952, dopo l'invaso del bacino idroelettrico, a $3,8 \mathrm{~km} / \mathrm{sec}$.

Una delle cause che possono aver determinato tale diminuzione può essere individuata nell'aumentata porosità della roccia.

E noto infatti che l'aumento di porosità nella roccia si traduce appunto in una diminuzione della velocità delle onde elastiche. Ricerche sull'argomento - e con questo risultato - furono condotte recentemente dal giapponese Satô $\left({ }^{1}\right)$.

Può essere griustificato un aumento della porosità nella roccia in spalla destra della diga di Pieve di Cadore, negli anni che vanno dal 1949 (epoca del primo invaso) al 1952?

3. - Osserviamo, a questo punto, che Pieve di Cadore fa parte di una zona ritenuta asismica. Non risulta infatti che movimenti sismici abljiano mai avuto origine in detta zona. Ciò non ostante il 13 gennaio 1950, a pochi mesi dal primo invaso, a diga ultimata, una sensiljile scossa di terremoto mise in allarme tutti i paesi rivieraschi del lago artificiale, da Pieve di Cadore a Calalzo, a Domegge, a Lozzo, ed altri paesi del retroterra, come Valle di Cadore e Perarolo.

Nel tendere verso nuove posizioni d'equilibrio, gli strati rocciosi sopportanti la diga e il bacino avevano superato il limite di rottura, provocando una sensibile scossa di terremoto, registrato in parecchi osservatori dell'Italia settentrionale e della Svizzera. L'energia da esso sviluppata risultò dell'ordine di $10^{17}$ erg.

Questo non è certo il primo esempio di scossa sismica provocata dalla creazione di un bacino artificiale. Per quanto ci risulta però è la prima volta che, subito dopo una scossa, un luacino idroelettrico viene sottoposto a sorveglianza da parte di una stazione sismica, posta opportunamente sulle sue sponde. È quanto noi abljiamo fatto, anche dietro richiesta della Società Adriatica di Elettricità, proprietaria del bacino idroelettrico in parola. Le caratteristiche dei sismografi sono 
riportate in altra pubblicazione $(\stackrel{2}{*}$. Diremo solo che si tratta di apparecchi a brevissimo periodo proprio, con registratore a forte scorrimento.

Le osservazioni dei movimenti nei pressi della diga furono completate con l'aggiunta di cinque coppic di clinografi, di cui quattro nell'interno della diga stessa ed una, in roccia, all'estremo destro della diga.

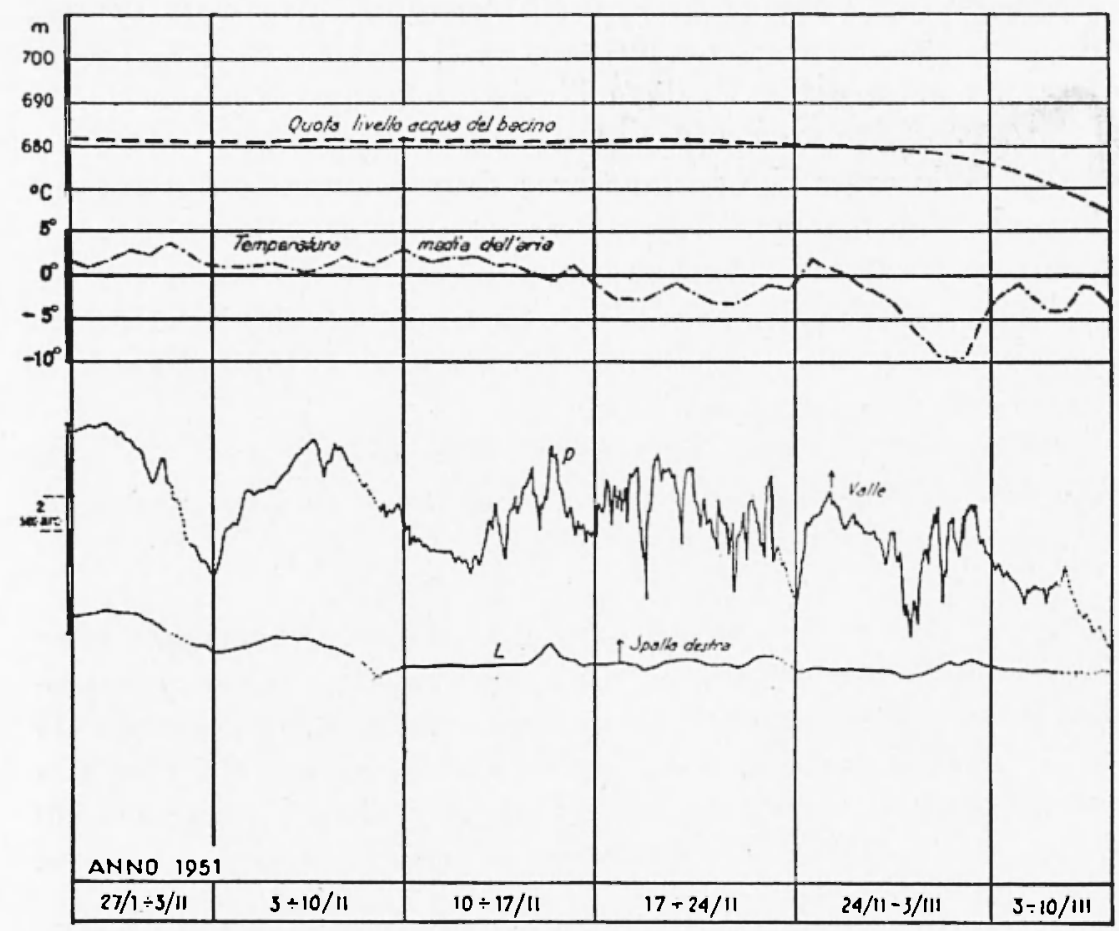

Fig 5

I dati raccolti dall'inizio del 1950 ad oggi hanno consentito di seguire, con continuità, i piccoli fenomeni sismici locali e la variazione della verticale apparente nei conci della diga.

La scossa di terremoto prima accennata è stata seguila da una serie di migliaia di piccole scossette strumentali, provenienti dal bacino, dalla luase della diga e dai sistemi rocciosi costituenti le spalle della diga stessa. La fig. 2 dà un esempio di un vero e proprio terremotino (passato inosservato dalla popolazione), con origine nel lago artificiale.

I clinografi, a loro volta, hanno rivelato l'esistenza delle ondula- 


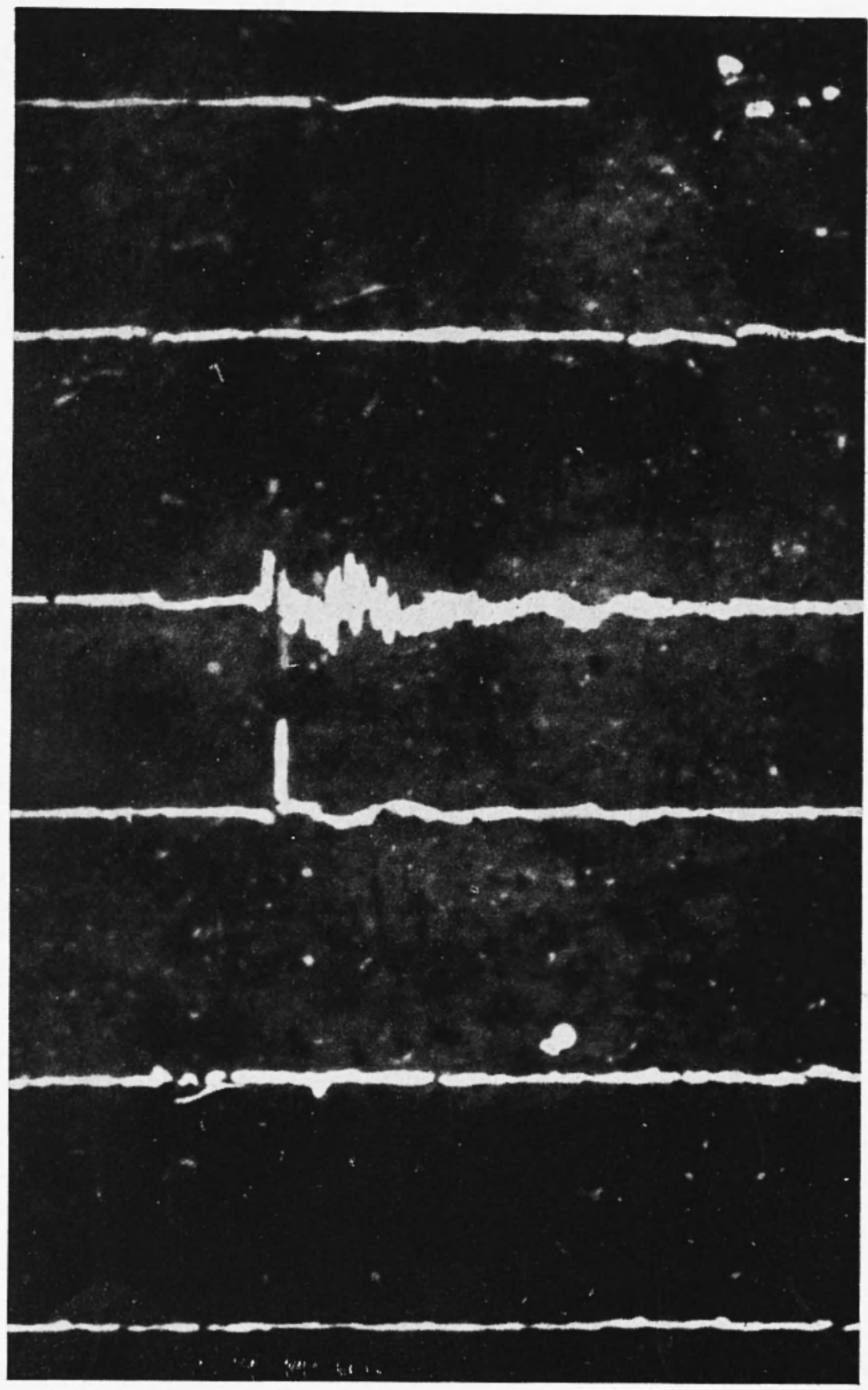

Fig. $5 a$. Scossette di energia media di $3.10^{11}$ erg. 


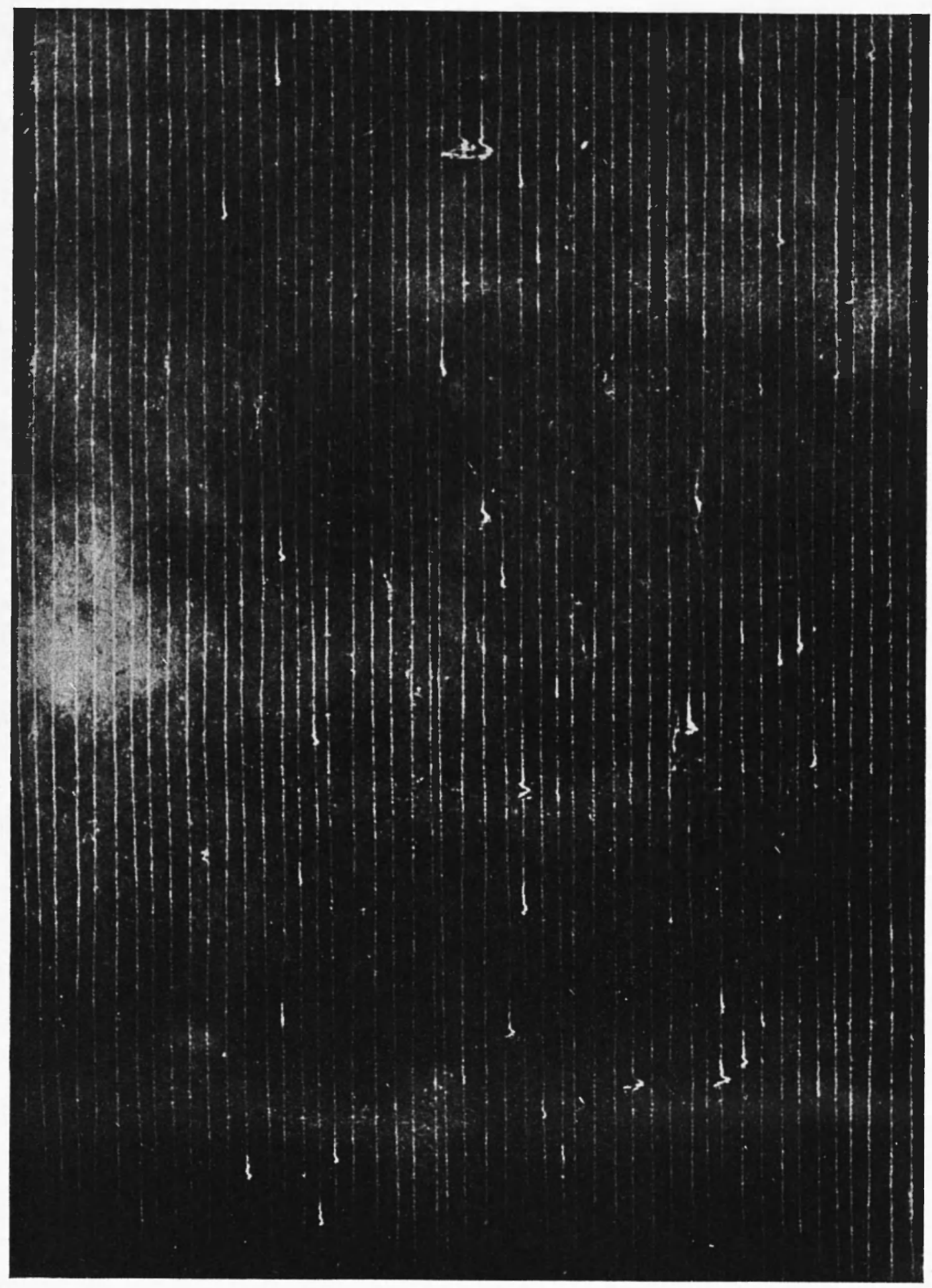

Fig. $5 b$ 


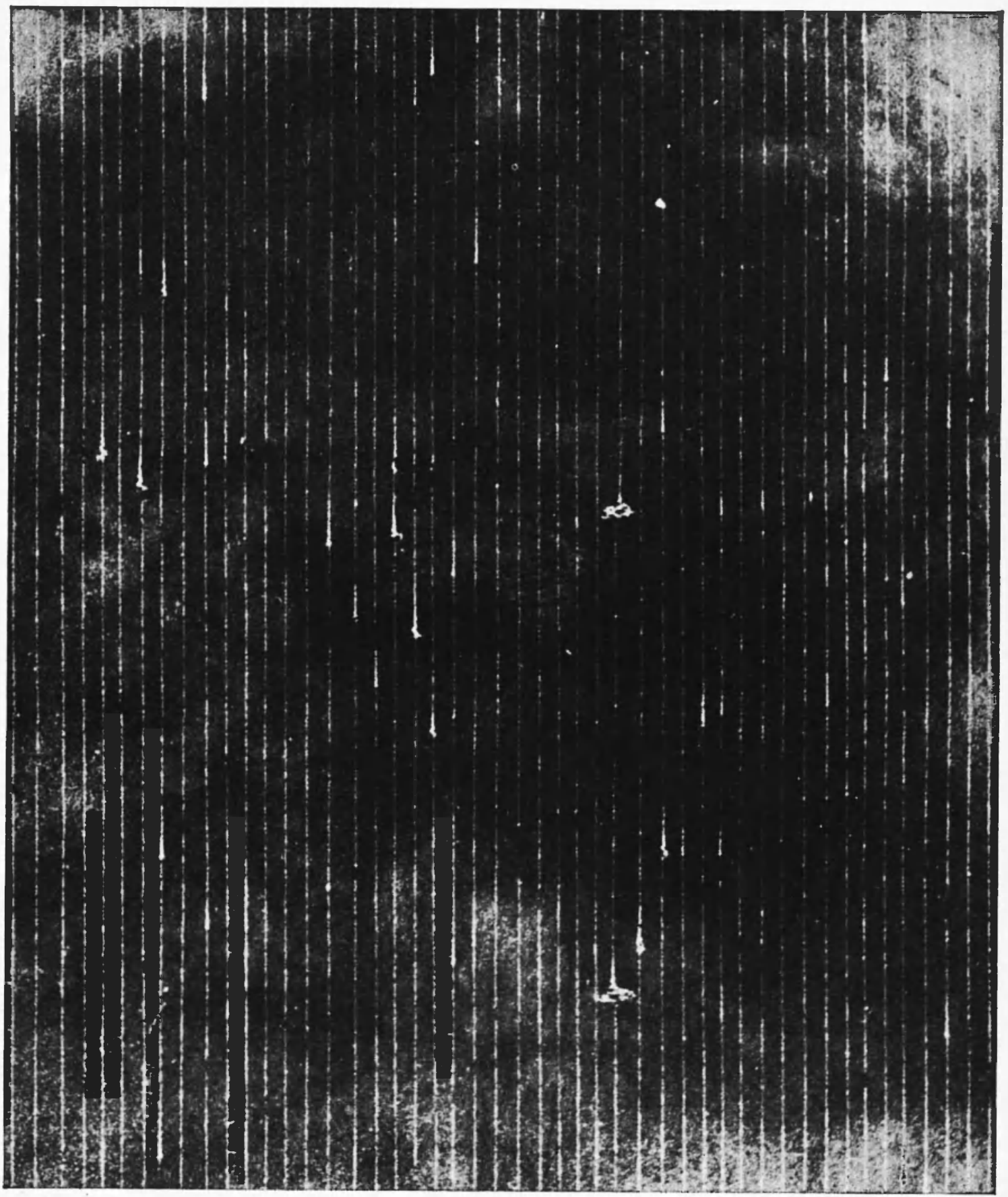

Fig. $5 c$ 
zioni di più varia provenienza: dalle onde diurne, dovute all'insolazione, alle sesse del lago, alle variazioni della verticale apparente determinate dai movimenti di blocchi geodetici confinanti.

Terminata la diga, a mano a mano che il bacino veniva riempiendosi d'acqua, si ebbe la registrazione di minutissime, piccole scosse, determinate da lievissimi scotimenti nel sistema roccioso, sospinto verso nuove posizioni d'equilibrio.

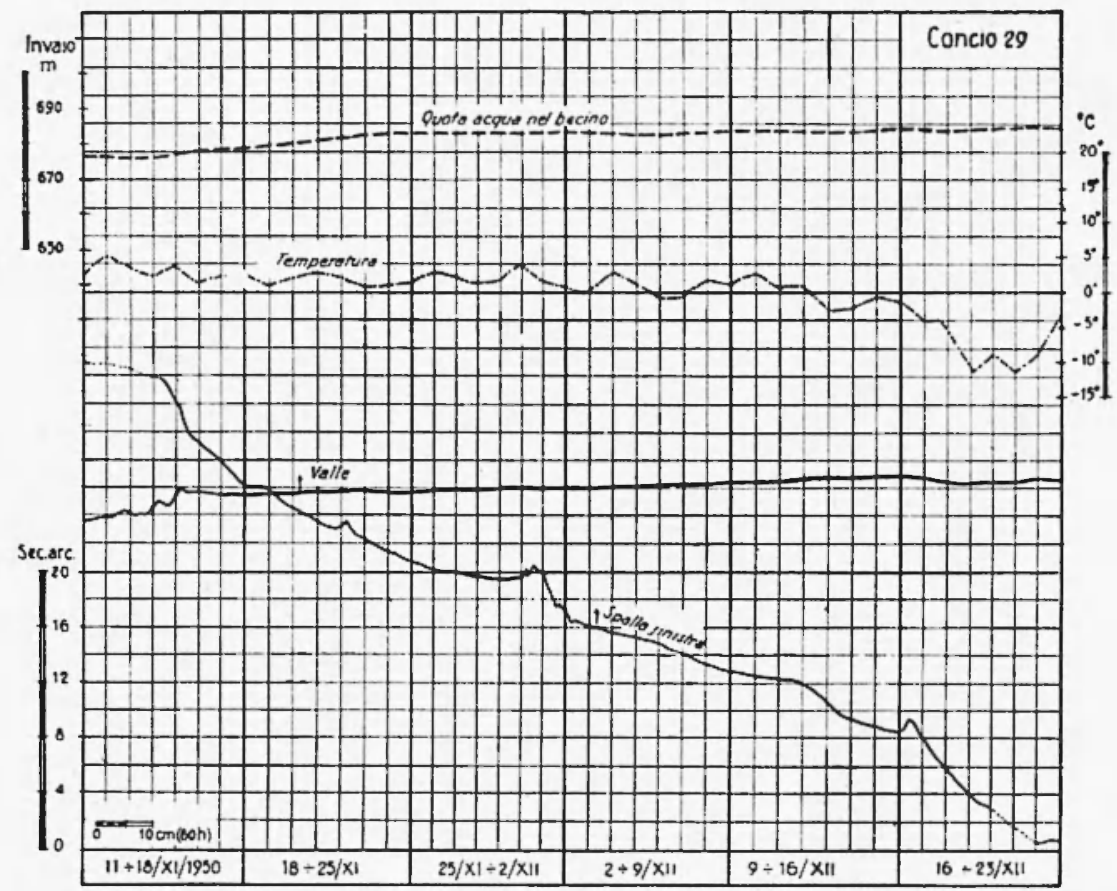

Fig. 6

In molti casi, fu possibile determinare la posizione-origine di queste scossette: la quasi totalità originava dalla parte del bacino, ove raggiungeva le massime profondità e dalla base della diga stessa.

La fig. 3 dà un esempio di registrazione di una scossetta, proveniente dal bacino idrico.

Anche durante i primi svasi, si ebbe un'accentuata registrazione di piccole scossette.

Molte di queste originano alla base dei conci, ed hanno caratteristiche speciali che le distinguono per la maggior frequenza e la persistenza delle vibrazioni (fig. 4). 
Si è potuto accertare che le piccole scosse osservate sono da attribuire a scorrimento lungo piccole fratture: la registrazione di segni iniziali contrari (dilatazioni e compressioni) per le onde longitudinali, sta a significare che il piano di frattura muta da una scossa all'altra o da una serie all'altra di piccole scosse. Questa interpretazione trova pure sostegno nel fatto che i centri di scotimento sono molteplici, sparsi un po' dovunque nell'area a ridosso della diga.

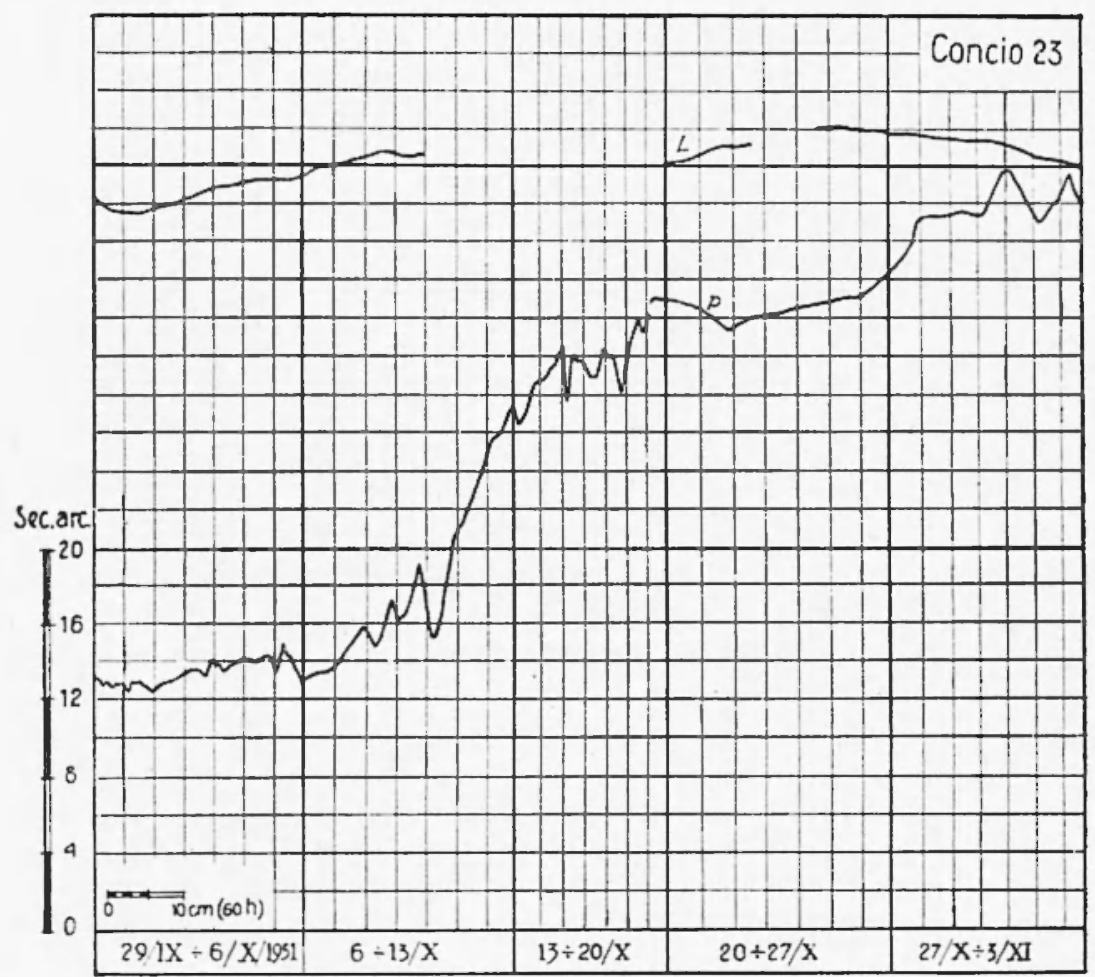

Fig. 7

Confrontando registrazioni clinografiche con registrazioni siemiche, si trova, in generale, una sorprendente relazione fra anormale attività microsismica e attività clinografica fuori del comune. Tale corrispondenza è tanto più stretta quanto più rapida è la variazione della verticale apparente.

Potremmo citare numerosi esempi a testimonianza di quanto è qui sopra affermato. Ci limiteremo a due.

Nel febbraio 1951 il concio XXIII della diga di Pieve di Cadore 


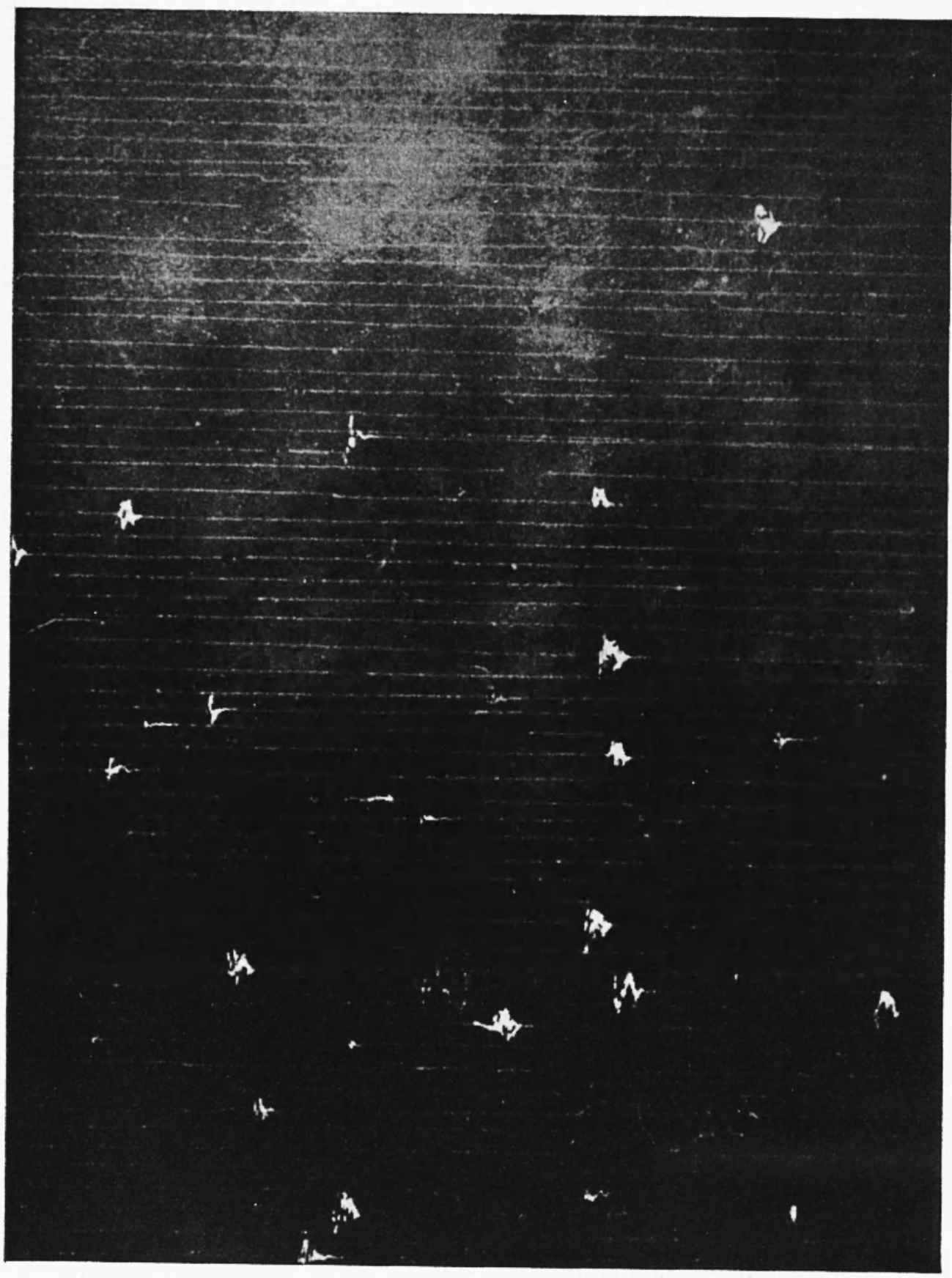

Fig. 8 


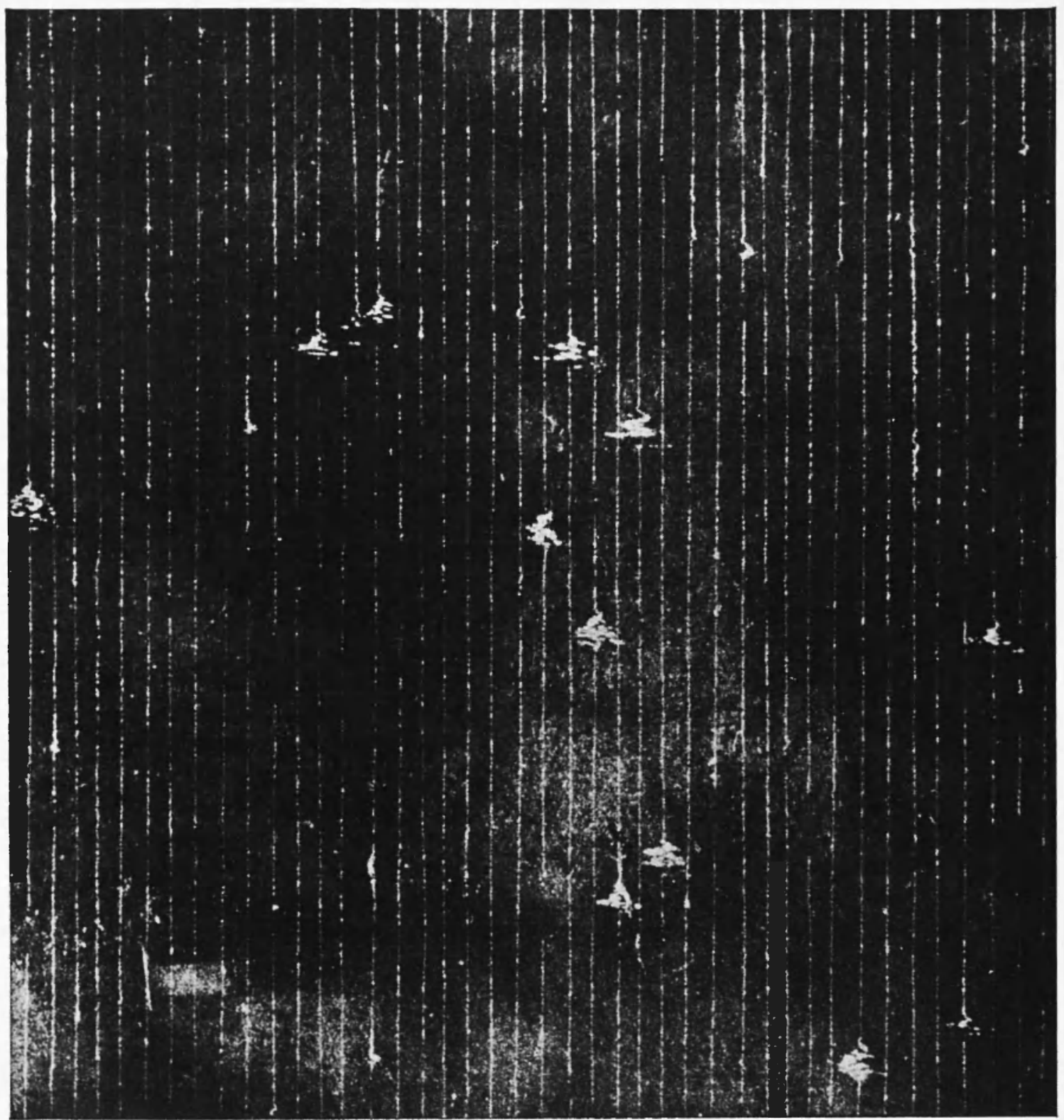


- e, presumibilmente, anche i conci limitrofi - accusa tutta una serie di movimenti rapidi, sovrapposti a quelli di più lungo periodo (fig. 5). Tali movimenti, evidentemente hanno sottoposto le rocce, entro cui sono infitti i conci, al tormento di continue brusche sollecitazioni: da qui il gran numero di piccole scosse, registrate in quel periodo dalla stazione sismica annessa alla diga (le figure 5-a, 5-b e 5-c forniscono qualche esempio).

Un altro periodo di eccezionale attività microsismica, osservata presso la diga di Pieve di Cadore, è quello legato alla fase di agitazione clinografica, iniziatasi ai primi di ottobre del 1951 (analogo a quello del 1950, fig. 6, concio XXIX) e della quale è già stato detto altrove (fig. 7). Proprio nei giorni in cui si ̀̀ verificata la massima flessione verso la spalla destra dei conci costituenti il lato destro della diga, con perfetta contemporaneità la registrazione delle scossette raggiunge la fase parossistica. Collateralmente al movimento clinografico dei conci, che dura, quasi senza interruzione, fino al termine del 1951, permane intensa l'attività sismica, a testimonianza dell'intimo legame fra lenti movimenti dei conci e piccoli bruschi moti sismici (figure 8 e 8-a). Nel caso citato, la flessione del complesso roccioso formante la spalla destra della diga fu tale da determinare uno spostamento permanente, come è provato dalle registrazioni della coppia di clinometri, funzionanti nella galleria in roccia della spalla destra (fig. 9).

Calcolata l'intensità media approssimativa dei vari tipi di piccole scossette, è stato possibile determinare l'ammontare approssimativo dell'energia liberata nel periodo considerato, dal settembre al dicembre $1951\left({ }^{2}\right)$. La fig. 10 dà una sintetica rappresentazione.

4. - Da quanto abbiamo esposto al n. 3 segue che, nel fondo roccioso che fa da letto ad un grande bacino idroelettrico, specie nelle sue parti a cui la diga viene ancorata, dal momento della formazione della trincea di dove la diga stessa sorgerà, al compimento del manufatto, al primo invaso e, in minor misura, agli svasi e invasi successivi, un continuo lavorio di assestamento è in atto, determinato dalla rottura del precedente equilibrio esistente fra le tensioni agenti nel mezzo. Il disturbo di questo equilibrio può manifestarsi in veri e propri terremoti o, comunque, in una miriade di piccoli scotimenti, che interessano la roccia tutt'intorno alla diga.

Quest'azione di tormento, continuata per anni, provoca nel mezzo roccioso minute fratture, innumerevoli piccole lesioni, che tendono ad aumentare la sua porosità, intesa in senso lato. Quest'azione mi- 


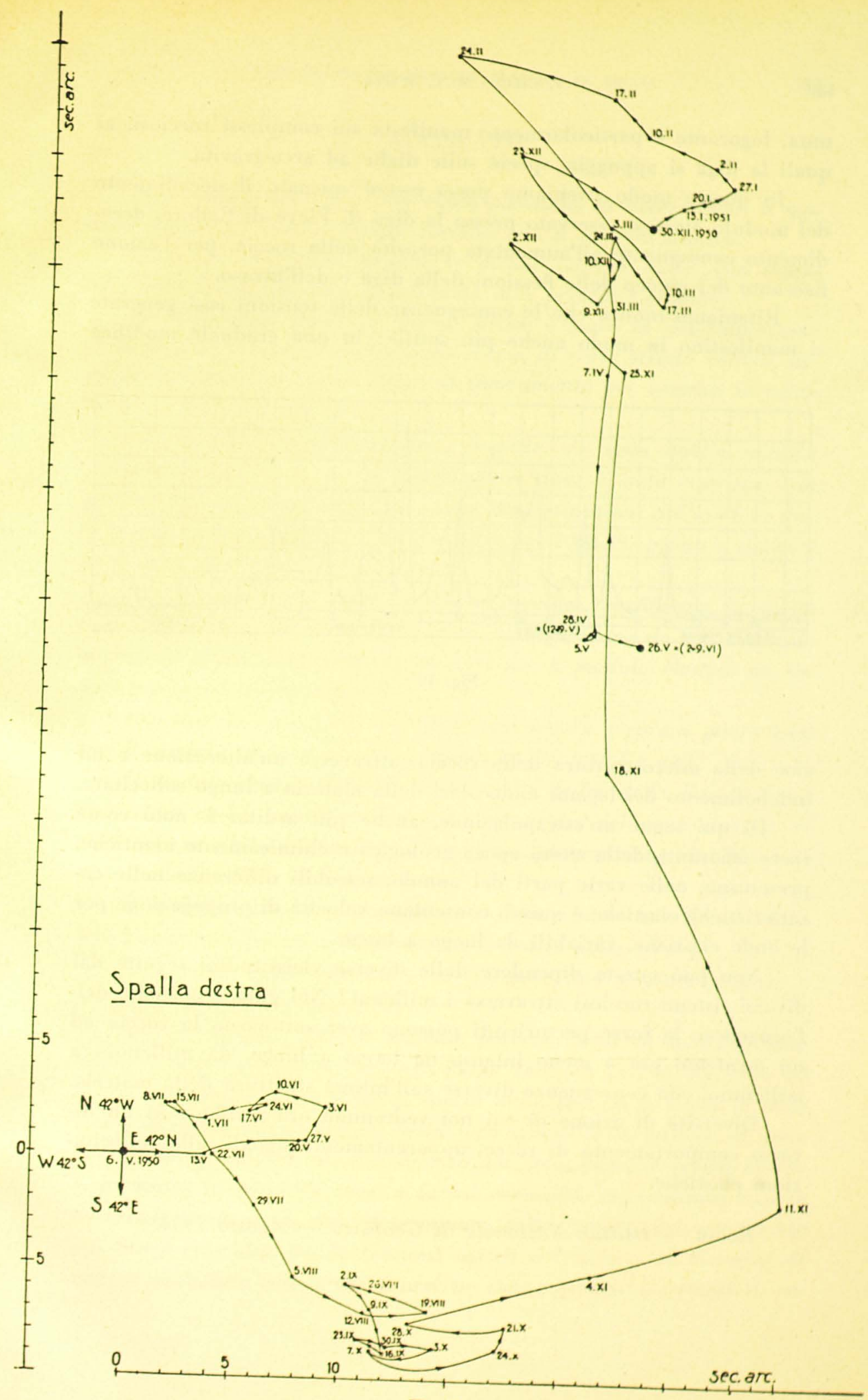

Fig. 9 
nuta, logorante è particolarmente manifesta sui complessi rocciosi, ai quali la diga si appoggia, specie sulle dighe ad arco-gravità.

In questo modo riteniamo possa essere spiegato il decadimento del modulo elastico osservato presso la diga di Pieve di Cadore, decadimento conseguente all'aumentata porosità della roccia, per l'azione fraccante del giuoco delle flessioni della diga e dell'invaso.

Riteniamo inoltre che le conseguenze delle tensioni cosi generate si manifestino in modo anche più sottile: in una graduale modifica

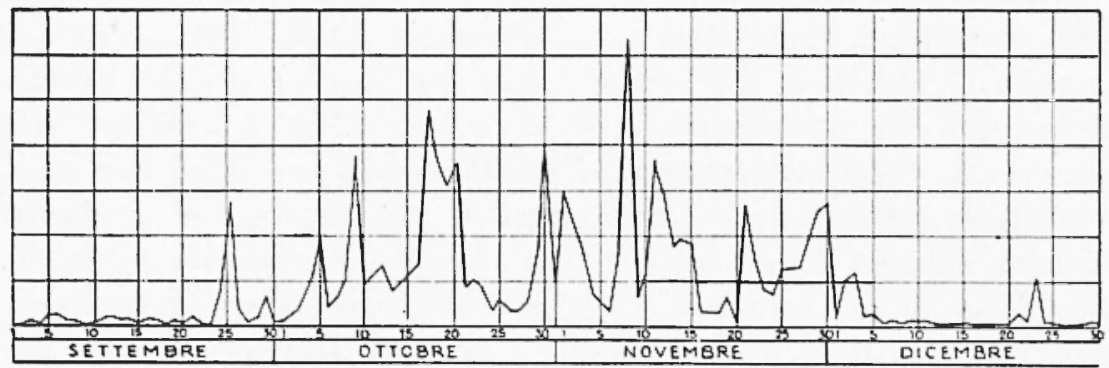

Fig. 10

ciò̀ della microstruttura della roccia, attraverso un'alterazione e un indebolimento dei legami molecolari della materia a lungo sollecitata.

Di qui segue un'estrapolazione, anche più ardita. È noto come rocce affioranti, della stessa epoca geologica e chimicamente identiche, presentino, nelle varie parti del mondo, sensibili differenze nelle caratteristiche elastiche e quindi consentano velocità di propagazione per le onde elastiche, variabili da luogo a luogo.

Non può questo dipendere dalle diverse vicissitudini seguite dai diversi sistemi rocciosi attraverso i millenni? Nel giuoco possente dell'orogenesi, le forze perturbanti possono aver sottoposto la roccia ad un tormento più o meno intenso da luogo a luogo, da millennio a millennio, con conseguenze diverse sull'intima struttura della materia.

Diversità di azione di cui noi vedremmo ora $i$ riflessi in un diverso comportamento di rocce, apparentemente uguali, alle sollecitazioni elastiche.

Roma - Istituto Nazionale di Geofisica - Agosto 1954. 


\section{RIASSUNTO}

Negli ultimi anni abbiamo avuto occasione di determinare il modulo elastico di diversi sistemi rocciosi con il metodo sismico.

Le prove sono state eseguite in alcune località delle Alpi orientali, dalle Dolomiti della Marmolada alle prealpi Carniche.

In molti casi, scopo di queste prove è stato la determinazione delle caratteristiche elastiche della roccia di certe strette vallive, destinate ad ancorare grandi dighe di sbarramento per contrali idroslettriche.

Fra le diverse determinazioni eseguite, c'ì stata quella relativa alla stretta del Piave a Pieve di Cadore, dove è stata costruita una grande diga di sbarramento. Le prime determinazioni del modulo della roccia in questa località furono fatte nel 1948-49, prima e durante la costruzione della diga stessa.

Per quanto riguarda il complesso roccioso, costituente la spalla destra della diga di Pieve di Cadore, le esperienze da noi condotte nellepoca detta, portarono ad ottenere per il modulo elastico un valore medio di $480.000 \mathrm{Kg} \mathrm{cm}^{2}$.

Ripetute le esperienze nel 1952, con nostra sorpresa ottenemmo per il modulo elastico il valore medio di $350.000 \mathrm{Kg} / \mathrm{cm}^{2}$.

Il modulo elastico della roccia in spalla destra della diga di Pieve di Cadore aveva quindi subito dal 1949, epoca del primo invaso, al 1952 una sensibile diminuzione: i a questa diminuzione che noi assegniamo la qualifica di decadimento.

Una delle cause che possono aver determinato tale diminuzione può essere individuata nell aumentata porosità della roccia.

Nei pressi della diga, sono in funzione una stazione sismica $e$ parecchie stazioni clinografiche.

Le registrazioni ottenute durante parecchi anni, ci hanno consentito di poter concludere che, nel fondo roccioso che fa da letto ad un grande bacino idroelettrico, specie nelle sue parti a cui la diga viene ancorata, dal momento della formazione della trincea di dove la diga stessa sorgerà, al compimento del manufatto, al primo invaso e, in minor misura, agli svasi e invasi successivi, un continuo lavorio di assestamento is in atro, determinato dalla rottura del precedento equilibrio esistente fra le tensioni agenti nel mezzo. Il disturbo di questo equilibrio può manifestarsi in veri e propri terremoti o, co- 
munque, in una miriade di piccoli scotimenti, che interessano la roccia tut'intorno alla diga.

Questazione di tormento, continuata per anni, provoca nel mezzo roccioso minute fratture, innumerevoli piccole lesioni, che tendono ad aumentare la sua porosità, intesa in senso lato. Quest'azione minuta, logorante è particolarmente manifesta sui complessi rocciosi, ai quali la diga si appoggia, specie nelle dighe ad arco-gravità.

In questo modo riteniamo possa essere spiegato il decadimento del modulo elastico osservato presso la diga di Pieve di Cadore, decadimento conseguente allaumentata porosità della roccia, per lazione faccante del giuoco delle flessioni della diga e dellinvaso.

Riteniamo inoltre che le conseguenze delle tensioni cosi generate si manifestino in modo anche più sottile: in una graduale modifica ciò̀ della microstruttura della roccia, attraverso un'alterazione e un indebolimento dei legami molecolari della materia a lungo sollecitata.

\section{SUMMARY}

In the last few years, we have had occasion to determine the elastic modulus of different rock systems with the seismic method.

The testing have been carried out in various localitics in the eastern Alps, from the Dolomites of the Marmolada to the Carniche pre-alps.

In many cases, the purpose of these tests has been the determination of the elastic characteristics of the rocks of certain narrow valleys which were destined to anchor large dams for hydroelectric centers.

Among the various determinations carried out, there was that for the narrous of the Piave to Pieve of Cadore, where a large dam has been constructed. The first determinations of the modulus of the rock in this region were made in 1948-1949, before and during the construction of the dam itself.

As regards the rock complex which constitutes the right shoulder of the dam of Pieve of Cadore, the tests carried out in the above epoch gave a mean value for the elastic modulus of $480.000 \mathrm{Kg} / \mathrm{cm}^{2}$.

The experiments were repeated in 1952, and surprisingly, the mean value of the elastic modulus as $350.000 \mathrm{Kg} / \mathrm{cm}^{2}$.

The elastic modulus of the right shoulder of this dam lad there- 
fore undergone, from 1949 to 1952, a very sensible diminution, which we will call a decay of the rock.

One of the reasons which might have lead to this diminution might have been an increase in the porosity of the rock.

A seismic station and several clinographic stations are in operation in the neighborhood of the dam.

The recording oblained during several years, have onabled as to conclude that, in the rock base that forms the bed of a large hydroolectric reservoir, especially in the sections where the dam has been anchored, from the moment of the culting of the trench from which the dam rises, to the completion of the work, at the first filling, and, to a less degree, for the successive excavations and fillings, a contimuous settling has been in progress, determined by the disruption of the previous equilibrium existing between the forces in the modium. The upsetting of this equilibrinm manifests itself in true earthquates, al leait in a myriad of small shocks, which disturb all of the rock in the vicinity of the dam.

This disturbing acting, continued for years, has provocaled minute fractures in the roct medium, and innumerable small lesions which have tended to increase the porosity, in a wide sense of the word. This small wearing action is manifested particularly in the romplex rocks on which the dam is supported, especially in dams of the archgravity type.

Wo sustain that the decline of the elastir modulus observed at the dam of Pieve of Cadore can bo explained as the increased porosity of the rock due to the disturbance on the play of the flexures of the dam and the fillings.

ITe find further that the consequences of the tensions thus generated are manifested in another more sublile way: in a gradual modification of the microstructure of the rock because of alteration and creatiening of the molecular bonds of the material under so long a strain.

\section{BIBIJOGRAFIA}

(1) Silo Y.. I rolocity of Elastic II ates Propagated in Media with Small Holes, "Bull. Ealthq. Res. Inst. ", Tokyo, XXX 110521.

1-) C.n,o1 P., Osservazioni sismiche e clinografiche presso grandi dighe di sbarramenk", "Inn. Geof." VI (1953). 